\title{
PENGENALAN PROSEDUR-PROSEDUR BAHASA INGGRIS DALAM PELATIHAN KETERAMPILAN PENGELASAN (PROSES SMAW) UNTUK PEMUDA DI RW 03, KWASEN LAMA, PONGANGAN, KECAMATAN GUNUNG PATI, KOTA SEMARANG
}

\author{
Rachmat Ari Wibowo \\ Teknik Kelistrikan Kapal, Fakultas Teknik, Akademi Teknik Perkapalan (ATP) Veteran \\ Jl. Pawiyatan luhur IV no. 18, Bendhan Duwur, Gajah Mungkur, Semarang 50235. \\ Email: rahmatariw40@gmail.com
}

\begin{abstract}
Abstrak
Bahasa Inggris adalah bahasa yang penting. Segala sesuatu di zaman modern menggunakan banyak bahasa Inggris, seperti manual perbaikan, peringatan tempat kerja, dan instruksi untuk menggunakan alat-alat teknis. Pengenalan prosedur bahasa Inggris mengenai pengelasan SMAW sangat penting karena dalam petunjuk untuk menggunakan peralatan pengelasan dan prosedur pengelasan disajikan dalam bahasa Inggris. Dengan diperkenalkannya pelatihan prosedur bahasa Inggris di RW 03, Kwasen Lama, Desa Pongangan, Kecamatan Gunung Pati, dapat meningkatkan kemampuan masyarakat untuk memahami instruksi dan prosedur untuk menggunakan peralatan pengelasan standar internasional, sehingga mereka dapat menggunakan alat-alat dan bekerja dengan tepat. Pengenalan prosedur bahasa Inggris dalam pengelasan dihadiri oleh 15 remaja di desa Pongangan. Pengenalan prosedur bahasa Inggris menerima tanggapan positif dari masyarakat. Hasil evaluasi beberapa peserta tidak dapat memahami penjelasan yang disajikan, ini disebabkan rendahnya tingkat pendidikan atau putus sekolah.
\end{abstract}

Kata Kunci: Pengenalan, Prosedur, bahasa Inggris, Pengelasan

\section{PENDAHULUAN}

Tri dharma perguruan tinggi meliputi pendidikan, penelitian dan pengabdian pada masyarakat. Pada awal tahun 2018 ini ATP telah melaksanakan kegiatan pengabdian pada masyarakat yang merupakan salah satu tugas pokok perguruan tinggi. Kegiatan tersebut berupa pelatihan ketrampilan dan kewirausahaan yang berkaitan dengan pengelasan dengan proses SMAW. Memilih pengenalan prosedur-prosedur bahasa Inggris tentang pengelasan SMAW karena dalam petunjuk penggunaan alat las berstandar internasional dan tata cara pengelasannya disajikan dalam bahasa Inggris.

Kegiatan tersebut dilaksanakan di RW 03, Kwasen Lama, Desa Pongangan, Kecamatan Gunung Pati. Kegiatan tersebut dilaksansanakan dengan sasaran anak-anak muda usia produktif di lingkungan RW 03. Kegiatan meliputi pemaparan pengelasan SMAW dan penjelasan tentang prosedur pengelasan SMAW dalam bahasa inggris

Kegiatan pengabdian yang telah dilaksanakan tersebut juga menjalin kerjasama dengan berbagai pihak seperti CV. Lulus Jaya Powerindo sebagai tempat pelaksanaan pelatihan dan Akademi Pelayaran Niaga (AKPELNI) Semarang sebagai pemapar materi, keselamatan kerja, kewirausahaan dan penyedia alat untuk modal usaha.

Di zaman yang serba modern ini, bahasa inggris sangatlah penting. Segala sesuatu menggunakan bahasa Inggris, sebagai contoh buku pedoman reparasi, peringatan-peringatan di tempat kerja, dan petunjuk penggunaan alat teknik. Sebagai bahasa yang paling banyak dikenali oleh warga dunia, pemahaman mengenai bahasa inggris menjadi sangat vital dalam perjalanan karir. Era globalisasi memberikan peluang besar bagi masyarakat untuk dapat bekerja di dalam lingkungan internasional. Bukan tidak mungkin untuk bekerja pada perusahaan-perusahaan multinasional dengan prospek karir yang menjanjikan. Dalam pencapaiannya dibutuhkan kemampuan berbahasa Inggris yang baik untuk membuka peluang pekerjaan idaman, Berikut adalah keuntungan berbahasa inggris untuk pekerjaan:

1. Meningkatkan kepercayaan diri

Kemampuan bahasa berarti kemampuan berkomunikasi. Kemampuan berbahasa inggris membantu anda dalam berinteraksi dengan atasan, rekanan kerja, klien maupun customer 
dengan lebih efektif, yang secara langsung berpengaruh pada apresiasi terhadap profesionalitas anda. Dapat mengerti dan berkomunikasi secara aktif menggunakan bahasa internasional membawa keunggulan kualitas diri anda sehingga dapat meningkatkan kepercayaan diri anda di dunia kerja.

2. Meningkatkan peluang mendapatkan pekerjaan

Survey membuktikan bahwa hampur 55\% perusahaan di Indonesia mentutut karyawannya untuk dapat berkomunikasi di dalam bahasa inggris secara aktif. Tindakan tersebut adalah upaya peningkatan kredibilitas dan citra perusahaan mereka dalam meyakinkan klien dan investor untuk mempercayai produk/jasa mereka. Berbagai posisi dan bidang pekerjaan yang diminati bagi setiap-tiap individu memang berbeda, namun sering kali bahasa Inggris menjadi poin penting dalam penilaian kualitas sumber daya manusia di dalam segala bidang dan tingkatannya. Penguasaan bahasa Inggris pun menjadikan peluang anda semakin besar untuk mendapatkan pekerjaan yang diminati.

3. Membuka peluang untuk bekerja di perusahaan multinasional

Sebagaimana era modern yang semakin menghilangkan sekat-sekat interaksi ekonomi, ramainya investasi asing menghasilkan menjamurnya perusahaan multi nasional di Indonesia. Bagi anda yang menginginkan kesempatan untuk bekerja di perusahaan-perusahaan tersebut, sudah semestinya kemampuan dalam berbahasa Inggris menjadi salah satu skill yang anda miliki. Bahasa internasional seperti bahasa inggris di dalam perusahaan multinasional menjadi alat untuk memahami dan membagikan ide maupun pendapat anda terhadap perusahaan, dan juga menjadi kemampuan esensial di dalam melaksanakan tugas dan tanggungjawabnya terhadap perusahaanya yang dalam pengelolaannya membutuhkan bahasa Inggris.

4. Membuka kesempatan bekerja di luar negeri

Sebagai bahasa resmi atas 70 negara, bahasa Inggris telah mendominasi percakapan internasional sebagai bahasa paling populer di dunia. Besarnya penggunaan bahasa inggris di seluruh dunia serta kecanggihan teknologi perekrutan yang tidak terbatas pada jarak fisik antar negara membuat kesempatan untuk dapat bekerja di luar negeri semakin terbuka. Untuk dapat berhasil dalam kompetisi pekerjaan antar dunia yang semakin luas, maka kemampuan dalam berbahasa inggris semakin dibutuhkan untuk memperkaya kecakapan anda dalam pekerjaan, sehingga dapat dipercaya oleh negara-negara lain. Akan sulit bagi negara asing mempekerjakan masyarakat internasional yang tidak fasih berbahasa inggris dengan alasan menghindari hambatan bahasa dan miskomunikasi. Maka kemampuan berbahasa inggris menjadi semakin esensial dalam mencapai perusahaan yang menjadi impian anda.

Memang tidak semua pekerjaan mengutamakan kemampuan bahasa Inggris bagi kelancaran bisnisnya. Namun di era globalisasi yang tidak membatasi interaksi antar negara, sudah menjadi hal yang lumrah sebuah negara beradaptasi dengan lingkungannya untuk meningkatkan keuntungan ekonomi. Hal tersebut menjadi peluang bagi anda untuk terlibat langsung di dalam dunia profesionalitas internasional dibantu dengan penguasaan bahasa Inggris.

\section{METODE}

Metode yang digunakan dalam pelaksanaan pengabdian masyarakat di Desa Pongangan adalah metode pemaparan seperti perkuliahan, yang di dalamnya berisi pemaparan materi, diskusi dan tanya jawab. Langkah-langkah dalam melaksanakan pengabdian masyarakat ini, sebagai berikut:

1. Menjelaskan pengertian pengelasan SMAW dalam bahasa Inggris

2. Memberikan penjelasan tentang prosedur pengelasan SMAW dalam bahasa inggris

3. Menjelaskan macam/ tipe pengelasan SMAW dalam bahasa Inggris

4. Menjelaskan manfaat dan kerugian pengelasan SMAW dalam bahasa Inggris

5. Menjelaskan istilah istilah dalam pengelasan SMAW

\section{HASIL DAN PEMBAHASAN}

Setelah melaksanakan kegiatan pengabdian yang diikuti 15 pemuda dan sisanya masyarakat sekitar yang ingin mencoba atau sekedar ingin tahu, ternyata mereka sangat antusias mengikuti kegiatan pengenalan prosedur bahasa inggris karena belum pernah dilaksankan di dukuh kwasen.

Ketika dipaparkan tentang prosedur bahsa inggris dalam tata cara atau prosedur pengelasan SMAW, para peserta terlihat sangat antusias, sebagian besar mereka mengerti atau memahami dan ada 
pula sebagian dari mereka yang tertarik namun kurang dapat memahami, mungkin dikarenakan tingkat pendidikan mereka yang rendah ataupun putus sekolah. Namun untuk mereka yang berpendidikan minimal sekolah menengah tingkat atas atau sekolah menengah kejuruan tidak terlalu kesulitan memahami. Adapun Foto Kegiatan Pengenalan Prosedur-Prosedur Bahasa Inggris Dalam Pelatihan Keterampilan Pengelasan (Proses SMAW) Untuk Pemuda Di Rw 03, Kwasen Lama, Pongangan, Kecamatan Gunung Pati, Kota Semarang sebagai berikut:

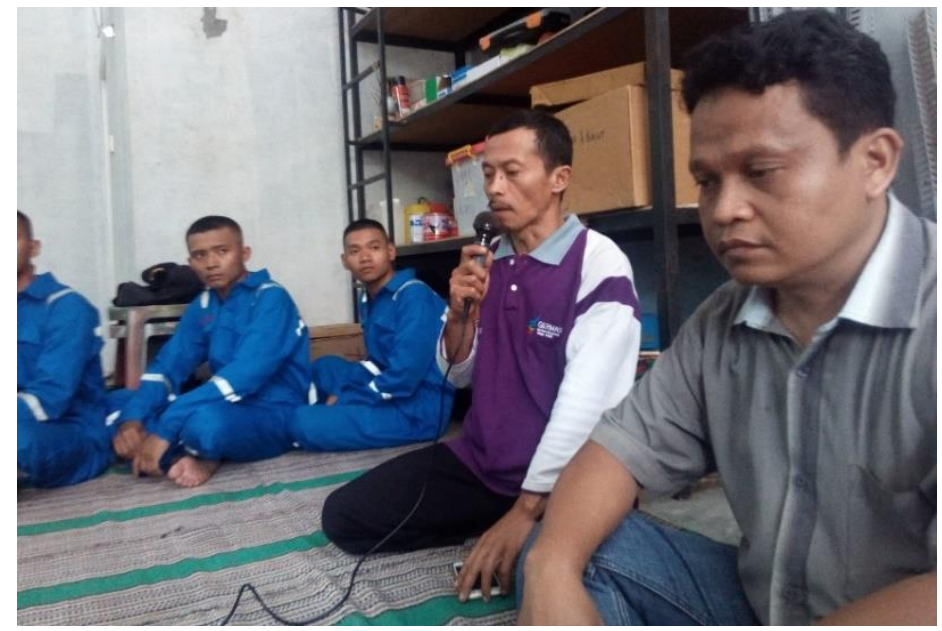

Gambar 1. Bpk Azhari memberikan sambutan mewakili warga RW 03 kel Pongangan

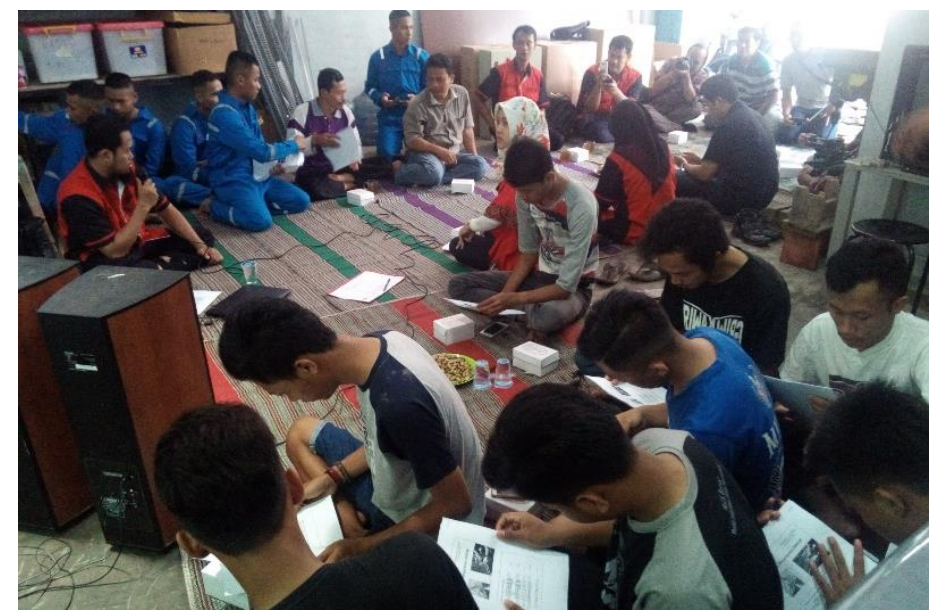

Gambar 2. Peserta mendengarkan penyampaian makalah 


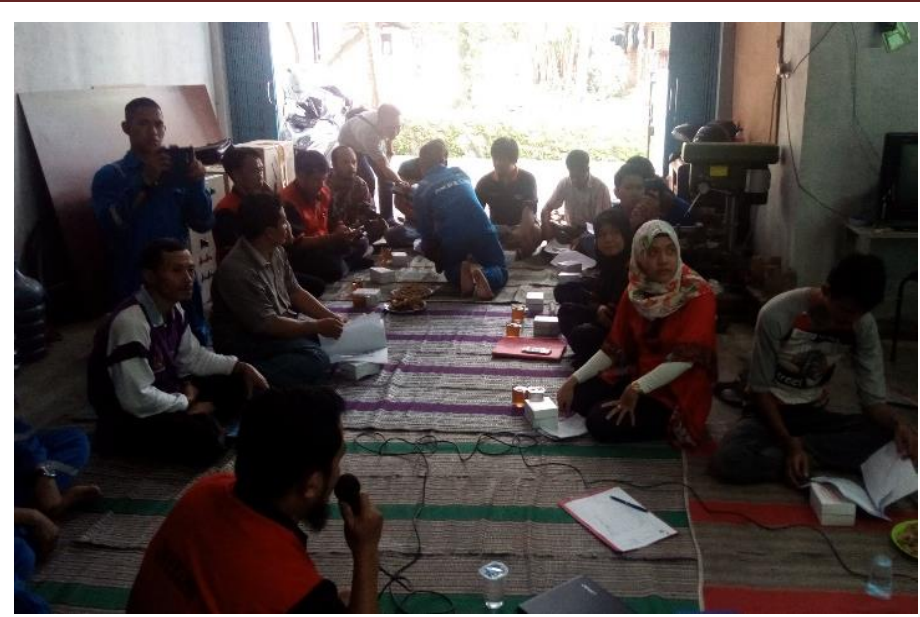

Gambar 3. Pemaparan materi prosedur bahasa inggris

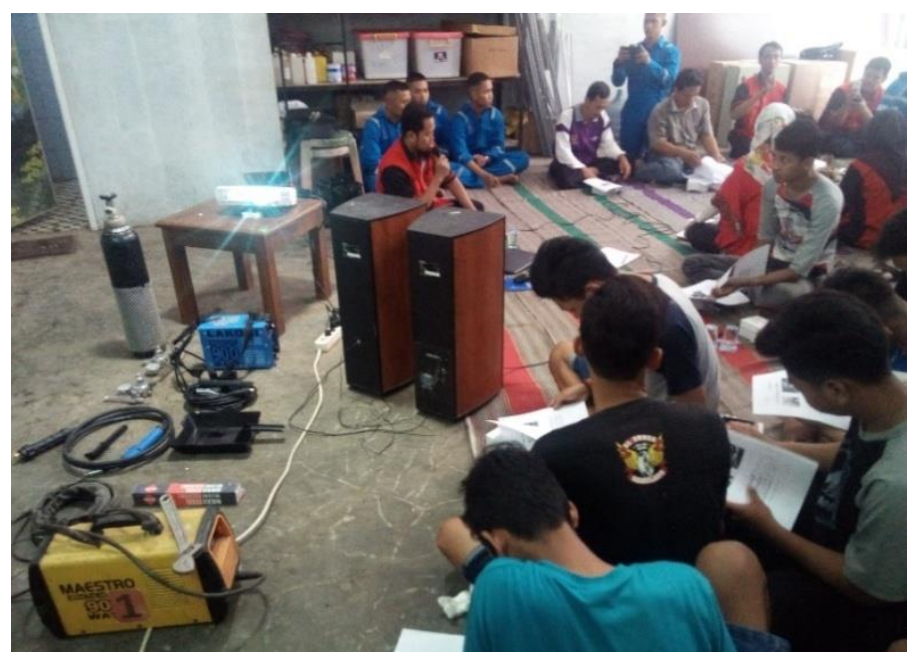

Gambar 4. Pengenalan jenis-jenis proses pengelasan SMAW, TIG, MIG

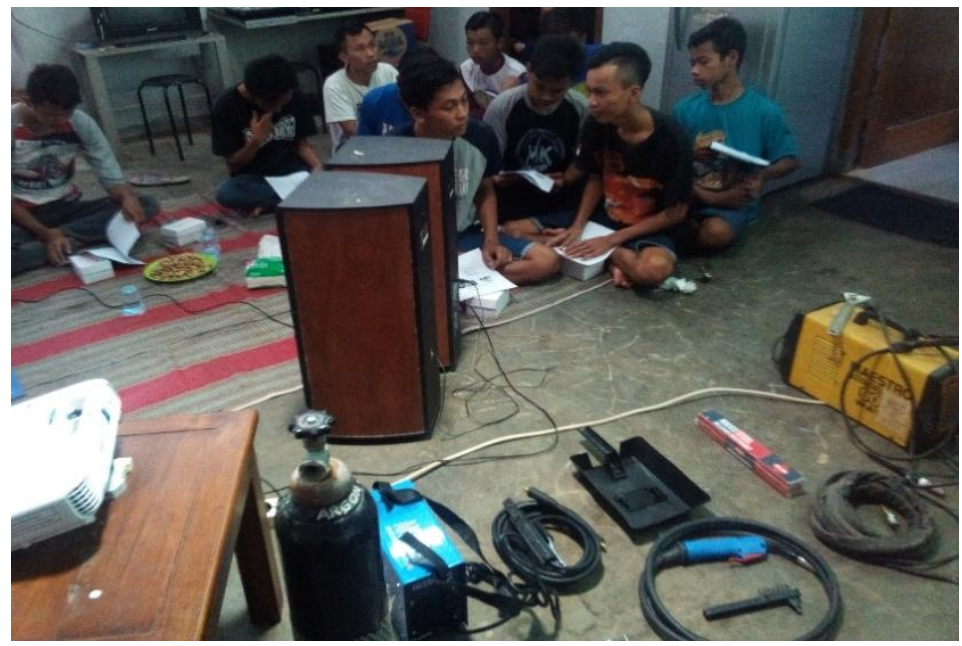

Gambar 5. Peralatan Pengelasan TIG/Argon, MIG dan SMAW 


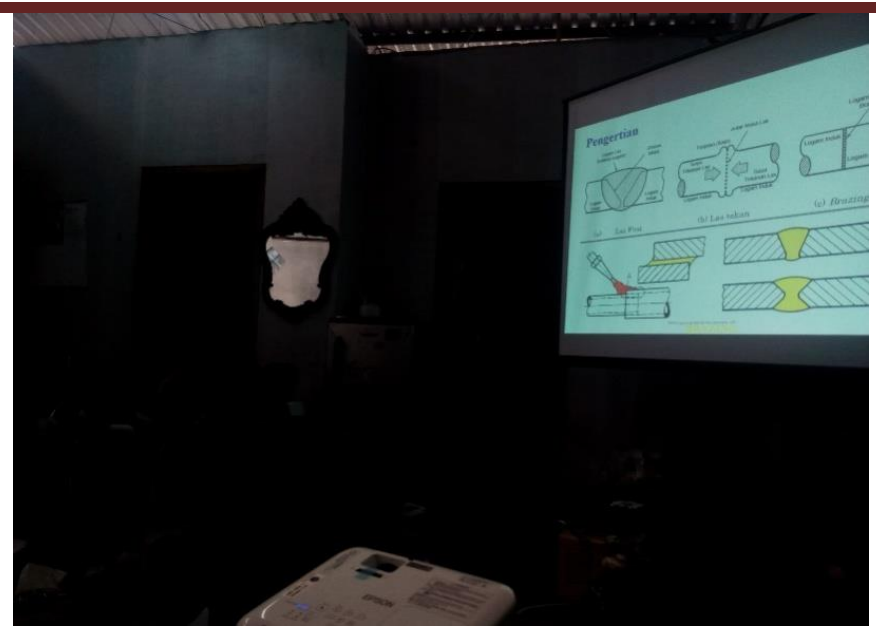

Gambar 6. Pemaparan materi dengan slide/proyektor

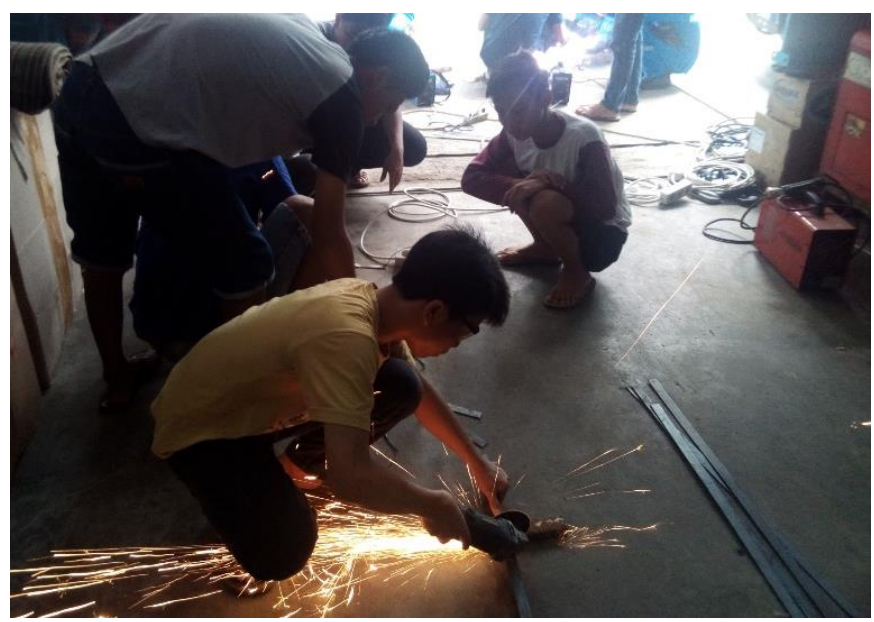

Gambar 7. Berlatih memotong plat dengan menggunakan gerinda potong

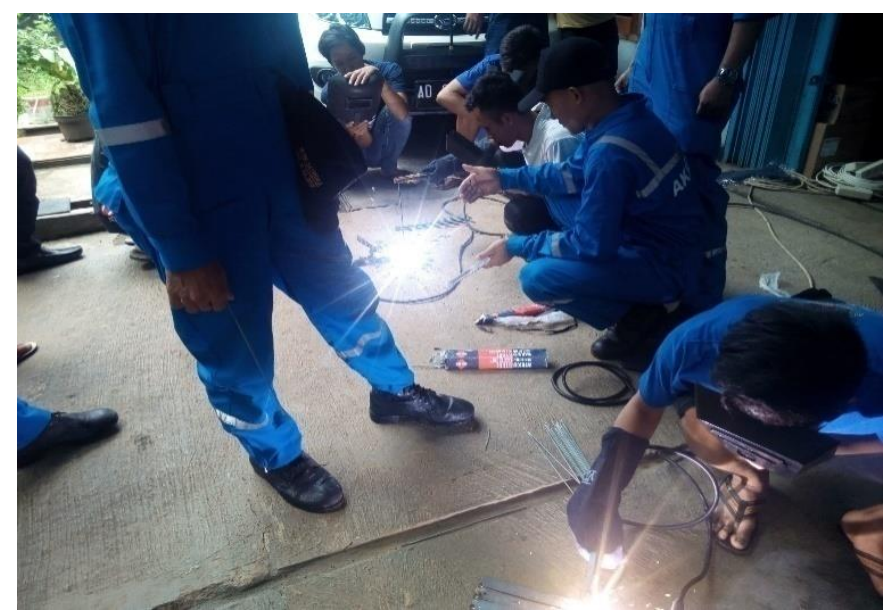

Gambar 8. Latihan pengelasan datar/flat didampingi taruna/mahasiswa 


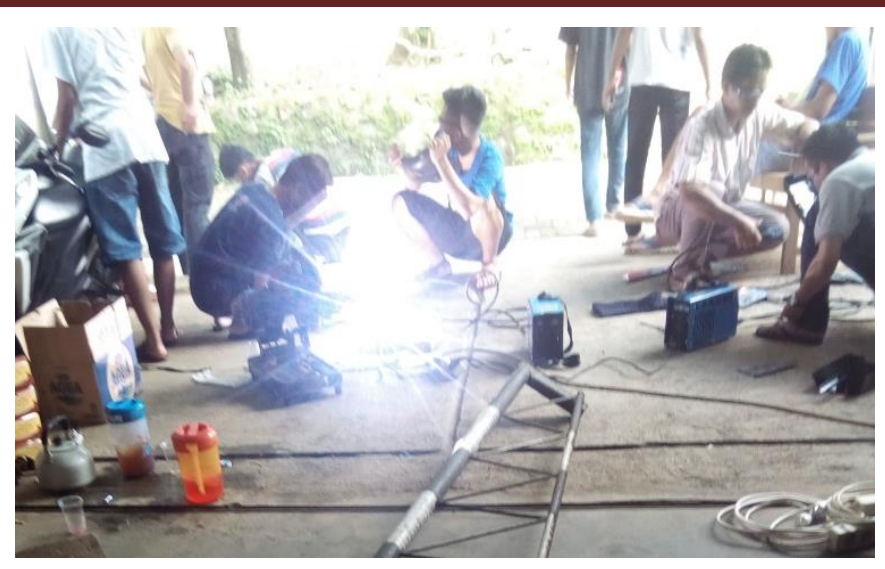

Gambar 9. Reparasi portal milik warga yang rusak

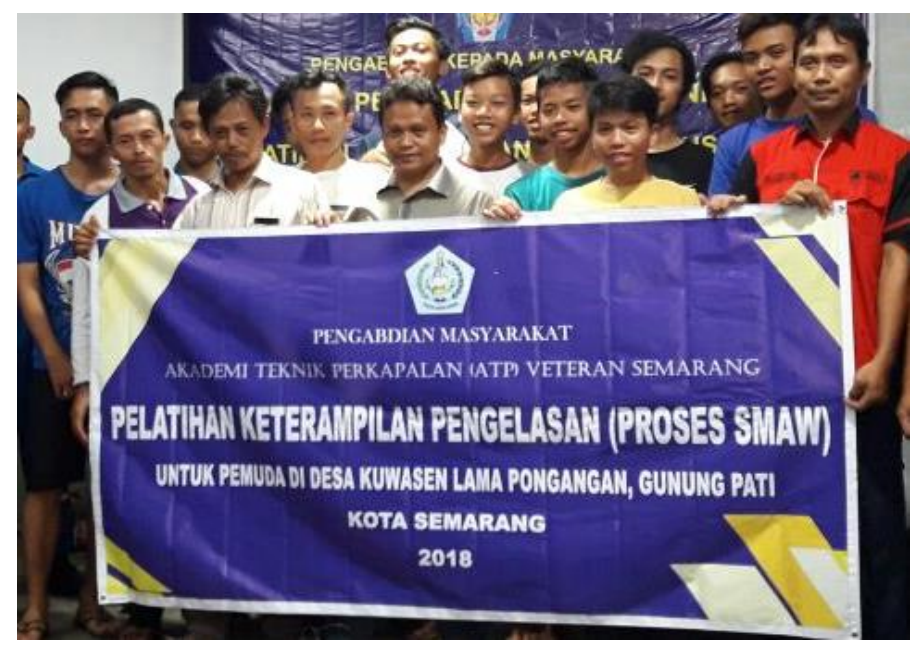

Gambar 10. Tim instruktur dari ATP Veteran Semarang bersama peserta pelatihan 


\section{METROPOLIS}

\section{Bola Voli Putra Kota Semarang Berjaya}

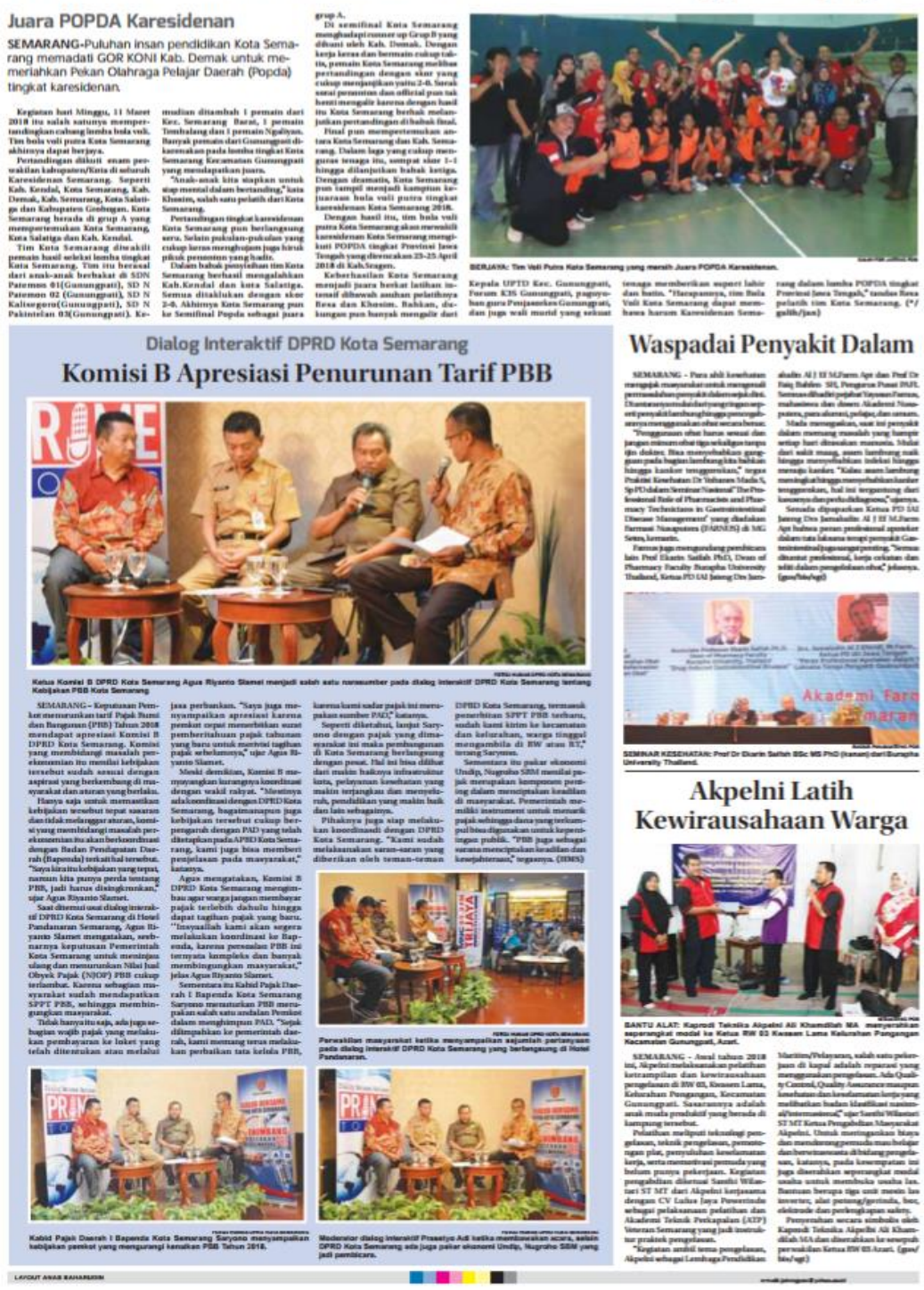

Gambar 11. Publikasi kegiatan bersama Akpelni, ATP dan CV.Tulus Powerindo di Jateng Pos Group Jawa Post 


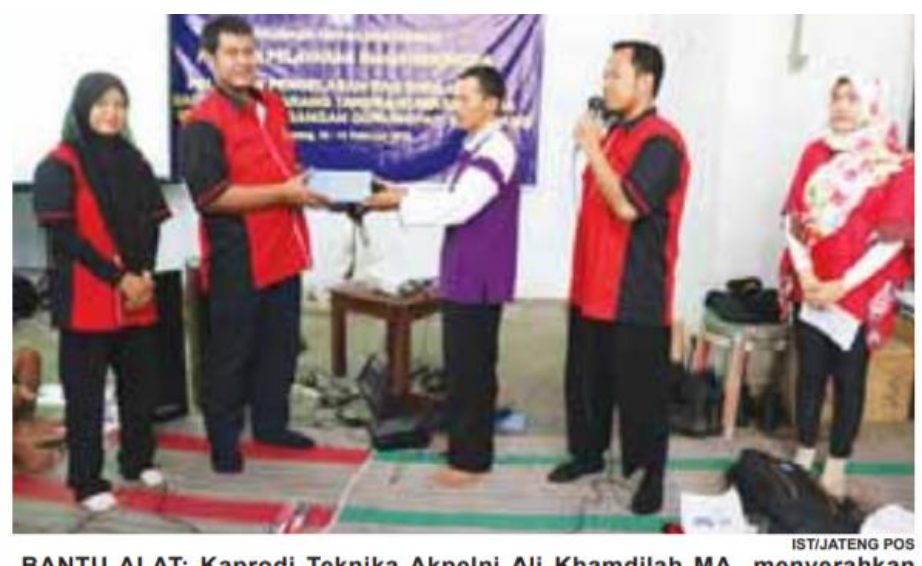

BANTU ALAT: Kaprodi Teknika Akpelni Ali Khamdilah MA menyerahkan seperangkat modal ke Ketua RW 03 Kwasen Lama Kelurahan Pongangan Kecamatan Gunungpati, Azari.

SEMARANG - Awal tahun 2018 ini, Akpelni melaksanakan pelatihan ketrampilan dan kewirausahaan pengelasan di RW 03, Kwasen Lama, Kelurahan Pongangan, Kecamatan Gunungpati. Sasarannya adalah anak muda produktif yang berada di kampung tersebut.

Pelatihan molingurengi pengela' 11 , teknik pengelasan, pemom gan plat, penyuluhan keselamatan kerja, serta memotivasi pemuda yang belum punya pekerjaan. Kegiatan engabdian diketuai Santhi Wilasta. ST MT dari Akpelni kerjasam dengan su uns Java Pow-rindo sebagai pelaksanaan pelatihan dan Akademi Teknik Perkapalan (ATP) Veteran Semarang yang jadi instruktur praktek pengelasan.

"Kegiatan ambil tema pengelasan, Akpelni sebagai Lembaga Pendidikan
Maritim/Pelayaran, salah satu pekerjaan di kapal adalah reparasi yang menggunakan pengelasan. Ada Quality Control, Quality Assurance maupun kesehatan dan keselamatan kerja yang melibatkan badan klasifikasi nasional/internasional," ujar Santhi Wilastari ST MT Ketua Pengabdian Masyarakat Akpelni. Untuk meringankan biaya dan mendorong pemuda mau belajar dan berwiraswasta di bidang pengelas. n, katanya, pada kesempatan ini ga diserahkan seperangkat modal saha untuk membuka usaha las. Bantuan berupa tiga unit mesin las inverter, alat potong/gerinda, bor elektrode dan perlengkapan safety.

Penyerahan secara simbolis oleh Kaprodi Teknika Akpelbi Ali Khamdilah MA dan diserahkan ke sesepuh perwakilan Ketua RW 03 Azari. (gus) bis/sgt)

\section{Gambar 12. Peran ATP Veteran Semarang dalam kegiatan bersama Akpelni dan CV Powerindo}

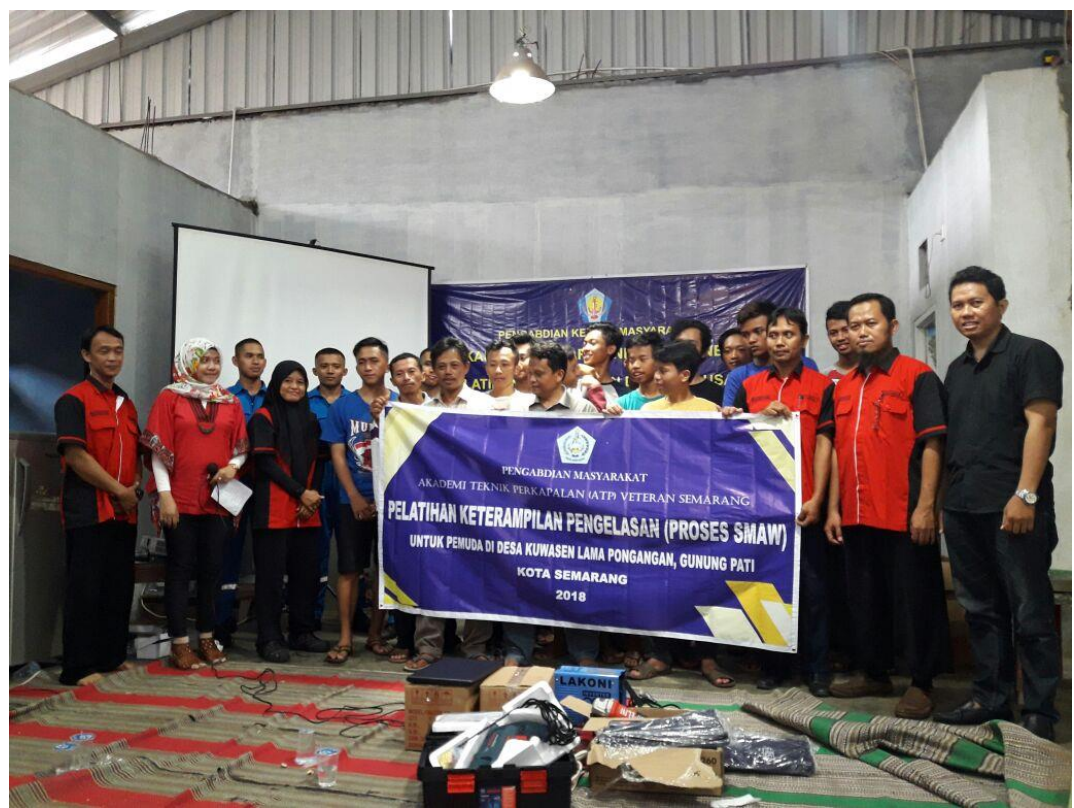

Gambar 13. Dokumentasi semua pemakalah yang terlibat 


\section{KESIMPULAN}

Ternyata dalam dunia kerja khususnya industri penguasaan basic English (bahasa inggris dasar) sangat penting karena di era globalisasi sekarang ini, sebagai contoh aturan pakai sebuah produk, atau tata cara penggunaan alat teknik menggunakan bahasa inggris. Untuk mengurangi resiko terjadinya kecelakaan dan hal hal yang tidak diinginkan, para pengguna alat teknik tersebut harus menguasai basic English atau paling tidak mengetahui arti dari istilah bahasa inggris yang tertera pada label produk mengetahui secara pasti fungsi dan penggunaan produk tersebut.

Ada pula fungsi dari penguasaan bahasa asing, salah satunya bahasa ingris adalah ketika kita bekerja di luar negeri yang mayoritas menggunakan bahasa inggris sebagai alat komunikasi,dan kemampuan berbahasa inggris menjadi salah satu syarat diterimanya seseorang di suatu industri di luar negeri.

\section{DAFTAR PUSTAKA}

Modul pelatihan dan sertifikasi Welding Inspector, Politeknik Perkapalan Negeri Surabaya, Surabaya, 2017

Welding theory, sub course,United States Army Combined Arms Support Command, Virginia, 2003

Welding: Design, procedure \& inspection, Department of the army, wasington, 1985 